\title{
Heat Stress Pre-Exposure May Differentially Modulate Plant Defense to Powdery Mildew in a Resistant and Susceptible Barley Genotype
}

\author{
Ildikó Schwarczinger ${ }^{1,+}{ }^{+}$Judit Kolozsváriné Nagy ${ }^{1,+}{ }^{\dagger}$, Lóránt Király ${ }^{1, * \mathbb{D}}$, Klára Mészáros ${ }^{2}$, Judit Bányai ${ }^{2}$, \\ Viola Kunos $^{2}$, József Fodor ${ }^{1}$ and András Künstler ${ }^{1}$ (D) \\ 1 Centre for Agricultural Research, Plant Protection Institute, ELKH, 15 Herman Ottó Str., \\ H-1022 Budapest, Hungary; schwarczinger.ildiko@atk.hu (I.S.); nagy.judit@atk.hu (J.K.N.); \\ fodor.jozsef@atk.hu (J.F.); kunstler.andras@atk.hu (A.K.) \\ 2 Centre for Agricultural Research, Agricultural Institute, ELKH, 2 Brunszvik Str., \\ H-2462 Martonvásár, Hungary; meszaros.klara@atk.hu (K.M.); banyai.judit@atk.hu (J.B.); \\ kunos.viola@atk.hu (V.K.) \\ * Correspondence: kiraly.lorant@atk.hu; Tel.: +36-1-487-7527 \\ + These authors contributed equally.
}

\section{check for}

updates

Citation: Schwarczinger, I.; Kolozsváriné Nagy, J.; Király, L.; Mészáros, K.; Bányai, J.; Kunos, V.; Fodor, J.; Künstler, A. Heat Stress Pre-Exposure May Differentially Modulate Plant Defense to Powdery Mildew in a Resistant and Susceptible Barley Genotype. Genes 2021, 12, 776. https://doi.org/10.3390/ genes12050776

Academic Editor: José M. Leitão

Received: 16 April 2021

Accepted: 17 May 2021

Published: 19 May 2021

Publisher's Note: MDPI stays neutral with regard to jurisdictional claims in published maps and institutional affiliations.

Copyright: (c) 2021 by the authors. Licensee MDPI, Basel, Switzerland. This article is an open access article distributed under the terms and conditions of the Creative Commons Attribution (CC BY) license (https:/ / creativecommons.org/licenses/by/ $4.0 /)$.

\begin{abstract}
Heat stress negatively affects barley production and under elevated temperatures defense responses to powdery mildew (Blumeria graminis f. sp. hordei, Bgh) are altered. Previous research has analyzed the effects of short-term ( $30 \mathrm{~s}$ to $2 \mathrm{~h}$ ) heat stress, however, few data are available on the influence of long-term exposure to heat on powdery mildew infections. We simultaneously assessed the effects of short and long term heat pre-exposure on resistance/susceptibility of barley to Bgh, evaluating powdery mildew infection by analyzing symptoms and Bgh biomass with RT-qPCR in barley plants pre-exposed to high temperatures $\left(28\right.$ and $35^{\circ} \mathrm{C}$ from $30 \mathrm{~s}$ to 5 days). Plant defense gene expression after heat stress pre-exposure and inoculation was also monitored. Our results show that prolonged heat stress $(24,48$ and $120 \mathrm{~h}$ ) further enhanced Bgh susceptibility in a susceptible barley line (MvHV118-17), while a resistant line (MvHV07-17) retained its pathogen resistance. Furthermore, prolonged heat stress significantly repressed the expression of several defense-related genes $(B A X$ inhibitor-1, Pathogenesis related-1b and Respiratory burst oxidase homologue F2) in both resistant and susceptible barley lines. Remarkably, heat-suppressed defense gene expression returned to normal levels only in MvHV07-17, a possible reason why this barley line retains Bgh resistance even at high temperatures.
\end{abstract}

Keywords: barley; BAX inhibitor; combined stress resistance; heat stress; pathogenesis-related genes; plant defense; powdery mildew infection; reactive oxygen species; respiratory burst oxidase homologue

\section{Introduction}

Plants are sessile organisms; therefore, a fast and efficient response to abiotic or biotic stresses is a key for their survival. When attacked by, e.g., pathogens, plants employ a variety of preformed and inducible defenses to prevent or at least limit infections. The first line of inducible plant defenses consists primarily of the pathogen-associated molecular pattern (PAMP) recognition system conferring a basal resistance (PAMP-triggered immunity, PTI) to a wide range of pathogens [1,2]. If the PAMP system fails to recognize the pathogen as an invader, susceptibility may develop, unless a second line of plant defense is induced by pathogen-secreted effectors when they are recognized by plant resistance $(R)$ proteins (effector-triggered immunity, ETI) [1,3]. ETI is often associated with a localized programmed cell/tissue death (PCD) at infection sites called the hypersensitive response (HR) [4]. The signaling processes leading to an HR involve, e.g., the accumulation of reactive oxygen species (ROS). ROS like superoxide $\left(\mathrm{O}_{2}{ }^{-}\right.$or hydrogen peroxide, $\left.\mathrm{H}_{2} \mathrm{O}_{2}\right)$ have a dual role during plant defense, as high ROS concentrations confer inhibition of invading 
pathogens along with PCD of infected plant cells (HR), while low ROS concentrations act as signals inducing antioxidants and pathogenesis-related (PR) genes and proteins in plant tissues adjacent to infection sites [5-9]. PR genes/proteins are induced by both pathogen infections and abiotic stresses but an early, enhanced induction occurs during incompatible host-pathogen interactions (i.e., resistance), as compared to compatible interactions [10], suggesting a role during disease resistance. Although several PR proteins exhibit antimicrobial activities (e.g., degradation of fungal cell walls via glucanase and chitinase activities), a direct functional role in defense could not be demonstrated for all PR proteins $[10,11]$. The PR1-b protein may contribute to resistance to fungal pathogens possibly by binding sterols in fungal membranes [12,13].

Powdery mildew fungi are obligate biotrophic pathogens that grow and reproduce only in living cells of infected plants by obtaining nutrients through specialized feeding structures called haustoria [14]. These ascomycete fungi comprise more than 700 species that regularly cause serious economic losses mostly in dicot crops [15]. In the 1990s, the majority of fungicides were applied in order to control powdery mildew diseases [16]. Barley powdery mildew, Blumeria graminis f. sp. hordei (D.C.), Golovin ex Speer f. sp. hordei Em. Marchal (Bgh), is one of the very few of these pathogens that can infect a monocot grass species, barley (Hordeum vulgare L.) $[17,18]$. Barley is the fourth cereal crop in relevance worldwide [19] and environmental stresses, e.g., heat stress, have a significant impact on its production [20]. Analysis of climate records has shown an increasing risk of exposure to heat stress that could result in the reduction of cereal yields up to $0.5 \mathrm{t} /$ ha by 2050 [21].

High temperatures interfere with various interconnected signaling pathways in plant cells, causing, e.g., an initially enhanced ROS production that contributes both to antioxidant induction (controlling ROS) and elevated expression of heat shock protein (HSP) genes encoding molecular chaperones that stabilize/protect, e.g., antioxidant enzymes. In addition, heat-induced extracellular $\mathrm{Ca}^{2+}$ influxes across plasma membranes activate heat shock transcription factors (HSFs) that regulate HSP expression, and $\mathrm{Ca}^{2+}$ is also responsible for activation of ROS-producing, disease resistance-associated NADPH oxidases. Importantly, the proper functioning of HSPs and antioxidant enzymes has been associated with the development of heat tolerance in several plant species (see [22,23] and references within).

While high temperature has negative or positive effects on plant pathogens as well $[23,24]$, temperature elevation is expected to favor both the emergence of new pathogens and the occurrence and severity of epidemics [25]. Plants in nature must face many different stresses simultaneously and biotic and abiotic stressors are acting in concert, both having a significant impact on plant health $[23,26]$. In addition, the interplay of abiotic and biotic factors may influence plant pathogen interactions and the outcome of a given infection [27,28]. In fact, most identified plant defense responses are altered under elevated temperatures, regardless of the plant and pathogen species [23]. Overall, a growing number of studies have shown that heat stress can affect the plant defense response in different ways, however, it can be concluded that heat stress has usually negative effects on key plant resistance mechanisms [23]: for example, higher mean temperatures observed over an experimental period of six years in wheat, correlated with elevated susceptibility to the fungus Cochliobolus sativus [29]. In cereals, the effects of temperature and other environmental conditions on powdery mildew infections have been reviewed by [30]. The optimum temperature for development of powdery mildew is $20^{\circ} \mathrm{C}$ [31] but the range at which it can infect and grow is wide. The upper limit for infection is about $30^{\circ} \mathrm{C}$ [32]. In spring barley, the primary leaves are highly susceptible to $\mathrm{Bgh}$, but when grown at $30^{\circ} \mathrm{C}$, the pathogen fails to infect its host [33].

The duration of heat stress is also an important factor in influencing plant defense [34]. A short term exposure to high temperatures (heat shock), e.g., submerging plants in $48-49^{\circ} \mathrm{C}$ water for 20 seconds (s) one day before Bgh inoculation, resulted in susceptibility of barley ( $\mathrm{H}$. vulgare $\mathrm{cv}$. Ingrid) near-isogenic lines containing different resistance genes (mlo5, Mlg, Mla12). In genetically susceptible barley (cv. Ingrid WT), the heat shock further 
increased susceptibility to Bgh [35]. In addition, we have shown that a short term heat shock $\left(49{ }^{\circ} \mathrm{C}\right.$ for $45 \mathrm{~s}$ ) partially suppresses symptomless nonhost resistance of barley to wheat powdery mildew (B. graminis f. sp. tritici) [36]. In some cases, however, short term exposure to elevated temperatures may increase resistance to plant pathogens. In barley (cv. Golden Promise), a $50{ }^{\circ} \mathrm{C}$ heat shock for $60 \mathrm{~s}$ induces resistance against Bgh $[37,38]$. On the other hand, more prolonged high temperatures seem to decrease plant disease resistance in barley. It has been presented that an exposure to $36^{\circ} \mathrm{C}$ for 30 minutes (min), 60 min and 120 min durations prior to pathogen inoculation causes enhanced susceptibility to Bgh in both genetically resistant (containing the mlo gene) and susceptible barley cultivars [39]. Interestingly, an exposure to high temperatures for several days combined with ambient or high carbon dioxide $\left(\mathrm{CO}_{2}\right)$ concentrations $\left(450 \mathrm{ppm} \mathrm{CO}_{2} / 26-30{ }^{\circ} \mathrm{C}\right.$ or $850 \mathrm{ppm} \mathrm{CO}_{2} /$ 26-30 ${ }^{\circ} \mathrm{C}$ ) inhibited wheat powdery mildew (B. graminis f. sp. tritici) growth independent of $\mathrm{CO}_{2}$ levels, and no typical powdery mildew symptoms were observed [24]. In this case, however, the absence of powdery mildew symptoms is presumably not due to the activation of plant defense responses but to the inhibition of pathogen growth at constant high temperatures. In summary, we find contradictory data about how heat stress may influence defense responses of barley to Bgh, probably because the plant cultivar, the powdery mildew race as well as the time between heat treatment and inoculation may differentially affect the barley/powdery mildew relationship at high temperatures.

We hypothesized that the duration of heat stress may significantly influence barleyBgh interactions and pre-exposure of plants to prolonged heat may dramatically increase their susceptibility to powdery mildew. In order to simultaneously assess the effects of short and long term heat exposure on resistance/susceptibility of barley to Bgh, the objective of the present study was to determine the influence of heat stress $\left(28\right.$ and $\left.35{ }^{\circ} \mathrm{C}\right)$ of different durations (from $30 \mathrm{~s}$ to five days) on barley defense responses to subsequent infections by Bgh in susceptible and resistant barley lines.

\section{Materials and Methods}

\subsection{Plant Materials and Pathogen Inoculation}

The following barley ( $H$. vulgare) cultivars and breeding lines were used in our experiments: cv. Ingrid Mlo; cv. GK-Stramm; cv. Antonella; cv. KWS-Meridian; cv. Hanzi; cv. MV Initium; MvHV05-17; MvHV07-17; MvHV14-18; MvHV118-17. Plants developed from approximately 30 seeds sown into two pots per treatment were grown in versatile environmental chambers $\left(20^{\circ} \mathrm{C}, 16 \mathrm{~h}\right.$ light $/ 8 \mathrm{~h}$ dark photoperiod $)$. To assess the host responses of the barley cultivars and breeding lines to barley powdery mildew, $B$. graminis f. sp. hordei (Bgh) race A6, artificial inoculation was performed. The Bgh race A6 used in this study was kindly supplied by Karl-Heinz Kogel (Justus Liebig University, Giessen, Germany). Bgh was maintained on susceptible host plants (cv. Ingrid Mlo) in versatile environmental chambers $\left(20{ }^{\circ} \mathrm{C}, 60 \%\right.$ relative humidity, $16 \mathrm{~h}$ photoperiod with a light intensity of $100 \mu \mathrm{mol} \mathrm{m} \mathrm{m}^{-2} \mathrm{~s}^{-1}$ ). For inoculation, conidia from heavily infected barley were dusted equally onto primary leaves of 7 day-old barley seedlings of the cultivars/lines listed above [36]. Inoculated plants showed an inoculation density of ca. 50 conidia $\mathrm{mm}^{-2}$. Bgh symptoms were evaluated visually 7 days after inoculation (DAI).

\subsection{Heat Stress}

To detect how heat stress influences powdery mildew infection, we artificially stressed a selected resistant (MvHV07-17) and susceptible (MvHV118-17) barley line prior to Bgh inoculation in versatile environmental chambers at $20^{\circ} \mathrm{C}$ (control), 28 and $35^{\circ} \mathrm{C}$ (heat stress) with a $16 \mathrm{~h}$ light $/ 8 \mathrm{~h}$ dark photoperiod. The reason for selecting 28 and $35{ }^{\circ} \mathrm{C}$ is that these temperatures may quite often occur under field conditions in Central Europe typically in periods when barley is exposed to Bgh (i.e., in May and June). The duration of heat stress ranged from $30 \mathrm{~s}$ to 5 days ( $30 \mathrm{~s}, 1 \mathrm{~min}, 1 \mathrm{~h}, 2 \mathrm{~h}, 6 \mathrm{~h}, 24 \mathrm{~h}, 48 \mathrm{~h}, 120 \mathrm{~h}$ ). For the longer (prolonged) heat stresses $(24,48$ and $120 \mathrm{~h}$ ), the temperature was decreased to 
$25^{\circ} \mathrm{C}$ during the $8 \mathrm{~h}$ dark period. Powdery mildew inoculation of heat stressed plants was performed as described above, immediately after heat treatments.

\subsection{Evaluation of Bgh Symptoms}

The formation of Bgh symptoms in leaves of inoculated plants was evaluated visually 7 days after inoculation. Disease severity was estimated as the percentage of area covered by powdery mildew symptoms per leaf. Inoculated primary leaves for each plant were evaluated. Three independent biological experiments were conducted and 360 plants per experiment were assessed.

\subsection{Quantitative Analyses of Powdery Mildew Biomass and Plant Defense Gene Expression}

To quantify Bgh biomass, leaf tissue samples ( 5 primary leaves from 5 individual plants randomly selected and pooled per treatment) were taken from plants at $7 \mathrm{DAI}$ in liquid nitrogen following symptomatic evaluation. Samples for defense gene expression ( 5 primary leaves from 5 individual plants randomly selected and pooled per treatment) were taken at early time points $(1,2,6$ and $24 \mathrm{~h})$ after heat stress or after heat stress immediately followed by Bgh inoculation, respectively, and stored at $-70^{\circ} \mathrm{C}$. To analyze Bgh biomass and plant defense gene expression, a reverse transcription followed by quantitative real-time polymerase chain reaction (RT-qPCR) method was used. Collected leaf tissue was grounded in liquid nitrogen and total RNA (including plant and Bgh RNAs) was isolated by the Plant Total RNA Extraction Miniprep System Kit according to the manufacturer's instructions (Viogene-Biotek Inc., Taipei, Taiwan). After RNA isolation, DNAse I treatment with RQ1 RNase-Free DNase was performed (Promega Inc., Madison, WI, USA). RNA quantity and quality (260/280 and 260/230 ratios) were assessed by a MaestroNano Spectrophotometer (Maestrogen Inc., Hsinchu City, Taiwan) and RNA degradation was also checked by formaldehyde agarose gel electrophoresis of total RNA. One-thousand ng total RNA was used for reverse transcription (RT) in each sample. RT was done with a RevertAid ${ }^{\mathrm{TM}} \mathrm{H}^{-}$cDNA Synthesis Kit (Thermo Fisher Scientific Inc., Waltham, MA, USA) according to the manufacturer's instructions. For negative control, a pool of randomly selected RNA samples were applied to which no reverse transcriptase was added. The qPCR for assaying relative expression of Bgh Glyceraldehyde 3-phosphate dehydrogenase (BgGAPDH) and barley defense genes BAX inhibitor-1 (HvBI-1), Pathogenesis related-1b (HvPR1-b) and Respiratory burst oxidase homologue F2 (HvRBOHF2) along with the barley reference gene Ubiquitin ( $\mathrm{HvU} U \mathrm{Ui}$ ) was conducted with the $2 \times$ SYBR FAST Readymix reagent (KAPA Biosystems Inc., Wilmington, MA, USA). The qPCR reactions were conducted as described by Höller et al. [40]. In brief, the PCR reaction mix contained $7.5 \mu \mathrm{L}$ KAPA SYBR FAST qPCR Master Mix (2X), $0.75 \mu \mathrm{L}$ of $5 \mu \mathrm{M}$ forward and reverse primers each, $3.5 \mu \mathrm{L}$ PCR-grade water and $2.5 \mu \mathrm{L}$ of 20 -fold diluted cDNA in $15 \mu \mathrm{L}$ total reaction volume. DNA amplifications were performed in a Bio-Rad CFX-96 real-time thermocycler (Bio-Rad Inc., Hercules, CA, USA), running a standard program $\left(95^{\circ} \mathrm{C}\right.$ for $2 \mathrm{~min}, 40$ cycles at $95^{\circ} \mathrm{C}$ for $10 \mathrm{~s}, 60^{\circ} \mathrm{C}$ for $10 \mathrm{~s}$ and $72{ }^{\circ} \mathrm{C}$ for $10 \mathrm{~s}$ ), followed by a melting curve analysis to determine amplicon specificity using a temperature range from 65 to $95^{\circ} \mathrm{C}$ with increments of $0.5^{\circ} \mathrm{C}$. Gene expression was normalized to a barley Ubiquitin gene ( $\left.\mathrm{Hv} \mathrm{Ubi}\right)$ as a reference. Previous research has shown that $\mathrm{HvUlbi}$ is a reliable reference gene for assaying gene expression changes in barley exposed to either powdery mildew infection, heat or drought stress [19,41-44]. The suitability of $\mathrm{HvU}$ Ubi as a reference gene was tested by analysis of cycle threshold (CT) variation in response to heat treatments and Bgh infection. Significant changes were not observed in CT values (mean \pm standard deviation, SD) for HvUbi during treatments. All reactions were performed using three independent biological experiments with three technical replicates per biological sample. In each run, water-only controls and non-reverse-transcribed RNA were used as negative controls. The primer efficiencies for the genes tested were between 101-106\%. Changes in gene expression were calculated using the $2^{-\Delta \Delta C T}$ method [45]. For primers used in qPCR, see Table 1. 
Table 1. Oligonucleotide primers used in qPCR.

\begin{tabular}{|c|c|c|c|c|c|}
\hline $\begin{array}{c}\text { Accession } \\
\text { Number }\end{array}$ & Gene & & Sequence $5^{\prime}-3^{\prime}$ & $\begin{array}{l}\text { Amplicon } \\
\text { Length }\end{array}$ & $\begin{array}{c}\text { Primer } \\
\text { Efficiency }\end{array}$ \\
\hline \multirow{2}{*}{ CAUH01004767 } & \multirow{2}{*}{$\begin{array}{l}\text { Glyceraldehyde 3-phosphate } \\
\text { dehydrogenase (BgGAPDH) }\end{array}$} & $\mathrm{F}$ & GGAGCCGAGTACATAGTAGAGT & \multirow{2}{*}{$105 \mathrm{bp}$} & \multirow{2}{*}{$106 \%$} \\
\hline & & $\mathrm{R}$ & GGAGGGTGCCG-AAATGATAAC & & \\
\hline \multirow{2}{*}{ M60175 } & \multirow{2}{*}{ Ubiquitin (HvUbi) } & $\mathrm{F}$ & ACCCTCGCCGA-CTACAACAT & \multirow{2}{*}{$240 \mathrm{bp}$} & \multirow{2}{*}{$102 \%$} \\
\hline & & $\mathrm{R}$ & AGTAGTGGCGGTCGAAGTG & & \\
\hline \multirow{2}{*}{ AJ290421 } & \multirow{2}{*}{ BAX inhibitor-1 (HvBI-1) } & $\mathrm{F}$ & ATGTTCTCGGTGCC-AGTCT & \multirow{2}{*}{$409 \mathrm{bp}$} & \multirow{2}{*}{$101 \%$} \\
\hline & & $\mathrm{R}$ & GGCGTGCTTGATGTAGTC & & \\
\hline \multirow{2}{*}{ X74940 } & \multirow{2}{*}{$\begin{array}{c}\text { Pathogenesis related }-1 b \\
(H v P R 1-b)\end{array}$} & $\mathrm{F}$ & GGACTACGACTACGGCTCCA & \multirow{2}{*}{$150 \mathrm{bp}$} & \multirow{2}{*}{$104 \%$} \\
\hline & & $\mathrm{R}$ & GGCTCGTAGTTGCAGGTGAT & & \\
\hline \multirow{2}{*}{ EU566856.1 } & \multirow{2}{*}{$\begin{array}{c}\text { Respiratory burst oxidase } \\
\text { homologue F2 (HvRBOHF2) }\end{array}$} & $\mathrm{F}$ & TGCTCGGTCAGCACT & \multirow{2}{*}{$175 \mathrm{bp}$} & \multirow{2}{*}{$105 \%$} \\
\hline & & $\mathrm{R}$ & TCCGCAATA GAACACTCC & & \\
\hline
\end{tabular}

Abbreviations: $F$, forward primer; $R$, reverse primer.

\subsection{Statistical Analyses}

Statistical analyses were carried out using the Statistica 13 software (TIBCO Software, Palo Alto, CA, USA). Powdery mildew coverage on the leaf and relative gene expression values were log transformed to achieve homogeneity of variances (assessed by Bartlett's test). Analysis of variance (ANOVA) and Tukey's post-hoc test were employed and differences at $p<0.05$ were considered as statistically significant.

\section{Results}

\subsection{Testing Different Barley Lines to Powdery Mildew Resistance}

In order to detect how barley (H. vulgare) plants respond to powdery mildew (B. graminis $\mathrm{f}$. sp hordei race A6) infection at a physiologically optimal temperature $\left(20^{\circ} \mathrm{C}\right)$, ten different barley cultivars and breeding lines (cv. Ingrid WT, cv. GK-Stramm, cv. Antonella, cv. KWS-Meridian, cv. Hanzi, cv. MV Initium, MvHV05-17, MvHV07-17, MvHV14-18, MvHV118-17) were tested. Artificial inoculation of the barley plants mentioned above was performed with Bgh race A6 and the formation of powdery mildew symptoms in infected leaves was evaluated visually 7 days after inoculation (Figure 1). Disease severity was estimated as the percentage of area covered by powdery mildew symptoms per leaf. Our results showed that no visible powdery mildew symptoms were detectable on GK-Stramm, Antonella, MvHV07-17, KWS-Meridian and MvHV05-17. However, KWS-Meridian and MvHV05-17 displayed a hypersensitive response (HR) (i.e., resistance associated with localized necrotic lesions) during infection. In contrast, MvHV14-18, MV Initium, MvHV118-17, Ingrid WT and Hanzi cultivars showed different levels of susceptibility to Bgh with visible powdery mildew symptoms on leaves (Figure 1).

\subsection{Determination of the Influence of Heat Stress on Powdery Mildew Infection}

To test how heat stress influences the defense responses of barley plants to Bgh, we selected two barley lines, one that displays no visible Bgh symptoms (MvHV07-17) and one susceptible line (MvHV118-17) which shows around 50\% powdery mildew coverage per infected leaf at $20^{\circ} \mathrm{C}$. These barley lines were subjected to high-temperature pretreatment of various durations immediately before Bgh inoculation. Subsequently, disease symptoms were visually evaluated at seven DAI. Our results showed that the resistant barley line MvHV07-17 retained its resistance to the pathogen even after previous exposure to high temperatures based on the extent of powdery mildew symptoms at 7 DAI (Figure 2). In contrast, in the MvHV118-17 susceptible line there was a significant increase in the proportion of powdery mildew-covered area in plants previously exposed to $35^{\circ} \mathrm{C}$ for 24,48 and $120 \mathrm{~h}$ (Figure 2). However, no significant enhancement of powdery mildew symptoms 
was observed following heat exposure for less than $24 \mathrm{~h}$ at $35^{\circ} \mathrm{C}$. Furthermore, $28^{\circ} \mathrm{C}$ heat stress enhanced susceptibility only at $48 \mathrm{~h}$ of heat treatment (Figure 2). In addition to the symptomatic assessment, the quantification of Bgh was also performed by RT-qPCR. These results were almost identical to the results of the symptom assessment; however, we found minor differences. As mentioned above, the resistant barley line MvHV07-17 retained its resistance to Bgh even after previous exposure to high temperatures; however, following a previous exposure to $35^{\circ} \mathrm{C}$ for $120 \mathrm{~h}$, the qPCR showed a significant increase in powdery mildew biomass, as compared to plants held at $20^{\circ} \mathrm{C}$ (Figure 2). The Bgh biomass significantly increased in the susceptible MvHV118-17 line previously exposed to $35^{\circ} \mathrm{C}$ for 24,48 and $120 \mathrm{~h}$; however, at $28^{\circ} \mathrm{C}$, a Bgh biomass increase was observed only following a 48 and $120 \mathrm{~h}$ of heat exposure. Interestingly, a short-term heat shock ( $30 \mathrm{~s}$ at 28 and $35^{\circ} \mathrm{C}$ ) significantly reduced the Bgh A6 biomass in MvHV118-17.
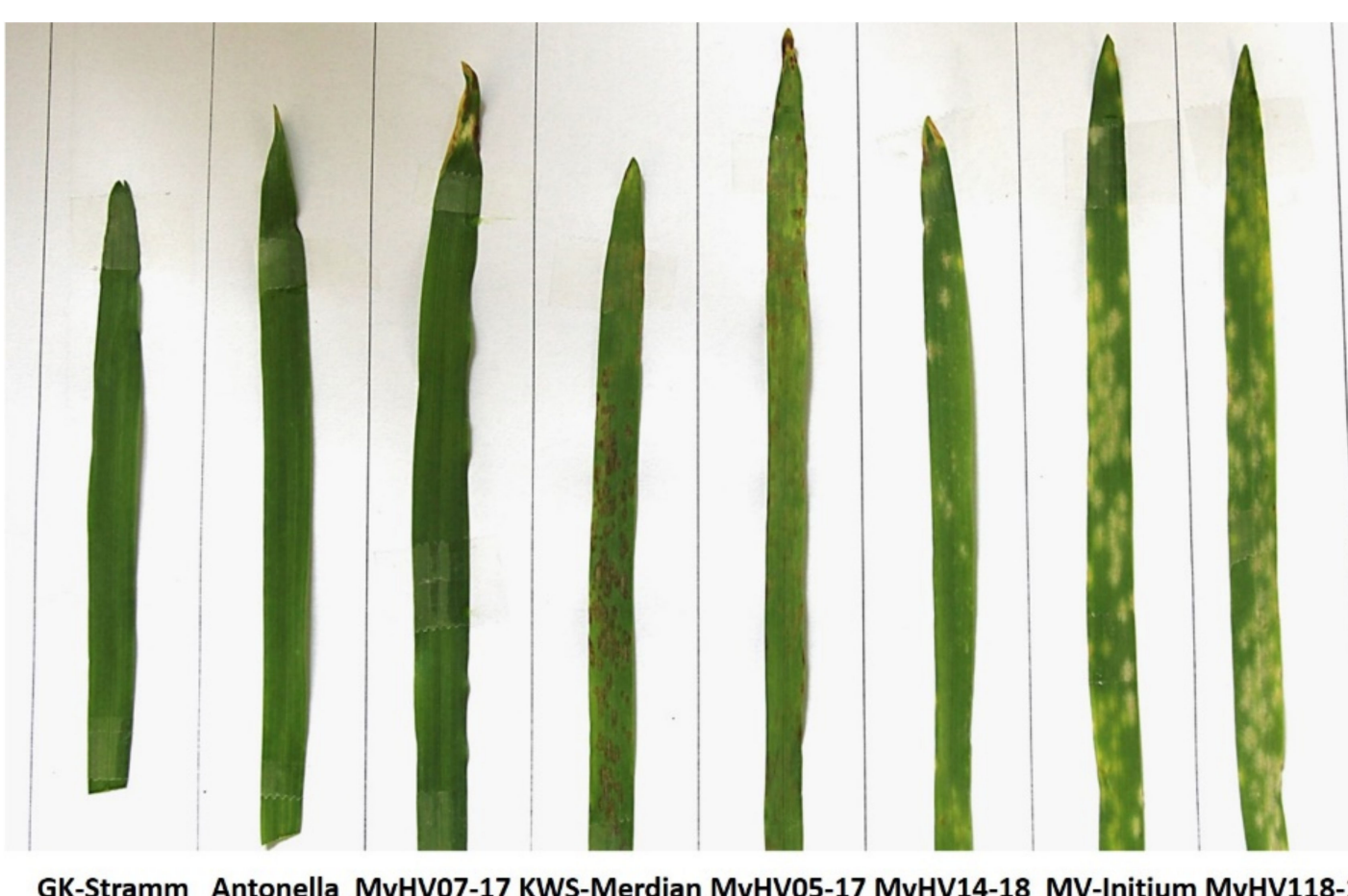

(R)

(R)

(R)

(R)

(R)

(S)

(S)

(S)

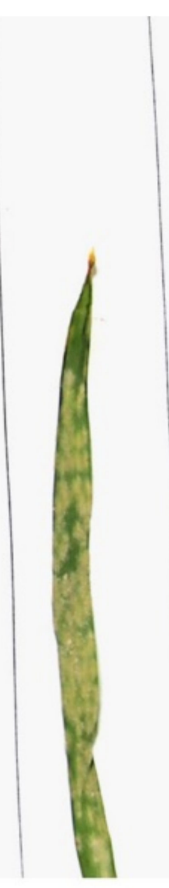

Ingrid

(S)

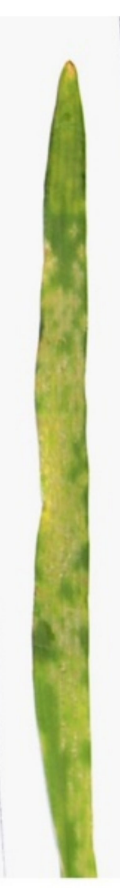

Hanzi

(S)

Figure 1. Absence or presence of powdery mildew (Blumeria graminis f. sp. hordei race A6; Bgh) symptoms in ten different barley cultivars and lines seven days after inoculation. Resistance or susceptibility of barley cultivars and lines to Bgh are marked with the letters (R) and (S).

Taken together, an enhancement of Bgh symptoms in the susceptible barley line (MvHV118-17) following exposure to $35^{\circ} \mathrm{C}$ for 24,48 and $120 \mathrm{~h}$ is detectable, as compared to the plants held at $20^{\circ} \mathrm{C}$. However, no Bgh symptoms were detectable in the resistant line (MvHV07-17), even at high temperatures (Figure 3). Based on the above results, long term $\left(24,48\right.$ and $120 \mathrm{~h}$ ) heat stress at $35^{\circ} \mathrm{C}$ significantly increased Bgh symptoms and biomass in the susceptible barley line MvHV118-17. In contrast, a short-term heat shock (30 s at $35^{\circ} \mathrm{C}$ ) did not influence Bgh symptoms but significantly reduced the Bgh biomass in line MvHV118-17 (Figure 2). 


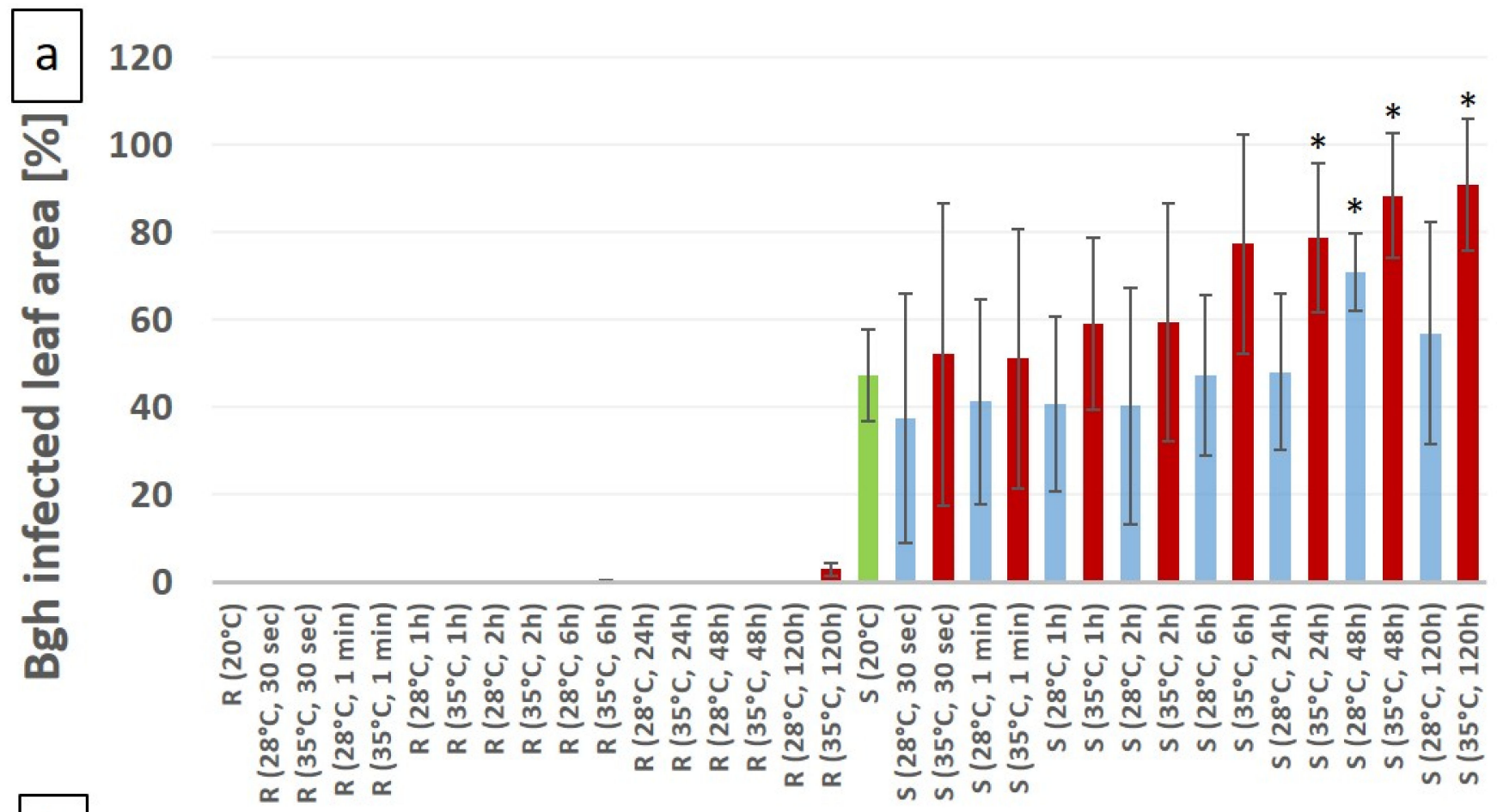

3.5

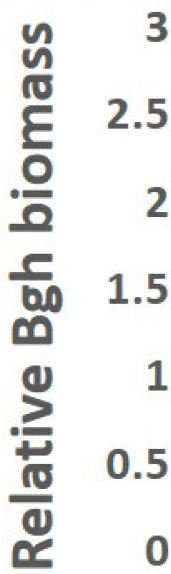

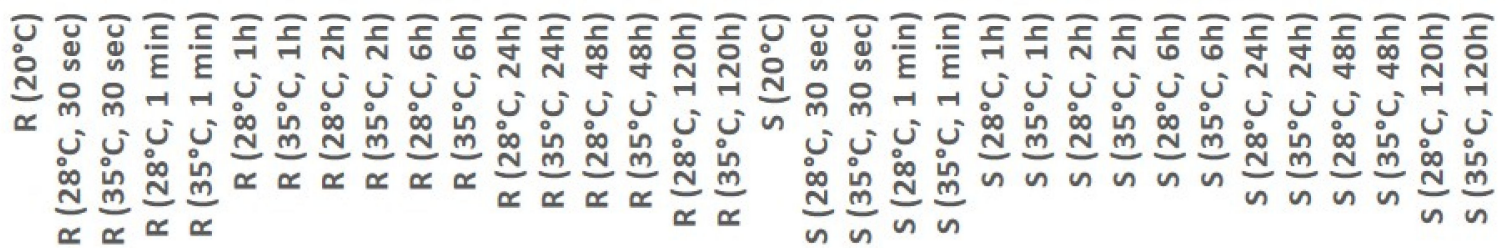

Figure 2. Evaluation of powdery mildew (Blumeria graminis f. sp. hordei A6, Bgh) symptom severity (a) in resistant (MvHV07-17; R) and susceptible (MvHV118-17; S) genotypes of barley seven days after inoculation. Barley plants were exposed to high temperature stresses $\left(28^{\circ} \mathrm{C}\right.$, blue columns and $35^{\circ} \mathrm{C}$, red columns) for different periods of time ( $30 \mathrm{~s}$ to $120 \mathrm{~h}$ ) before powdery mildew inoculation. Symptom severity was calculated as the percentage of area covered by powdery mildew symptoms per leaf. Non-heat treated plants were held at $20{ }^{\circ} \mathrm{C}$ (green columns). Relative Bgh biomass (b) in resistant (MvHV07-17; R) and susceptible (MvHV118-17, S) genotypes of barley seven days after inoculation. Barley plants were exposed to high temperature stresses as described above for (a). The graphs show the average of three experiments. Error bars represent standard deviation. Asterisks $\left(^{*}\right)$ indicate statistically significant differences between non-heat treated and heat treated plants within the respective barley genotypes at $p<0.05$. 


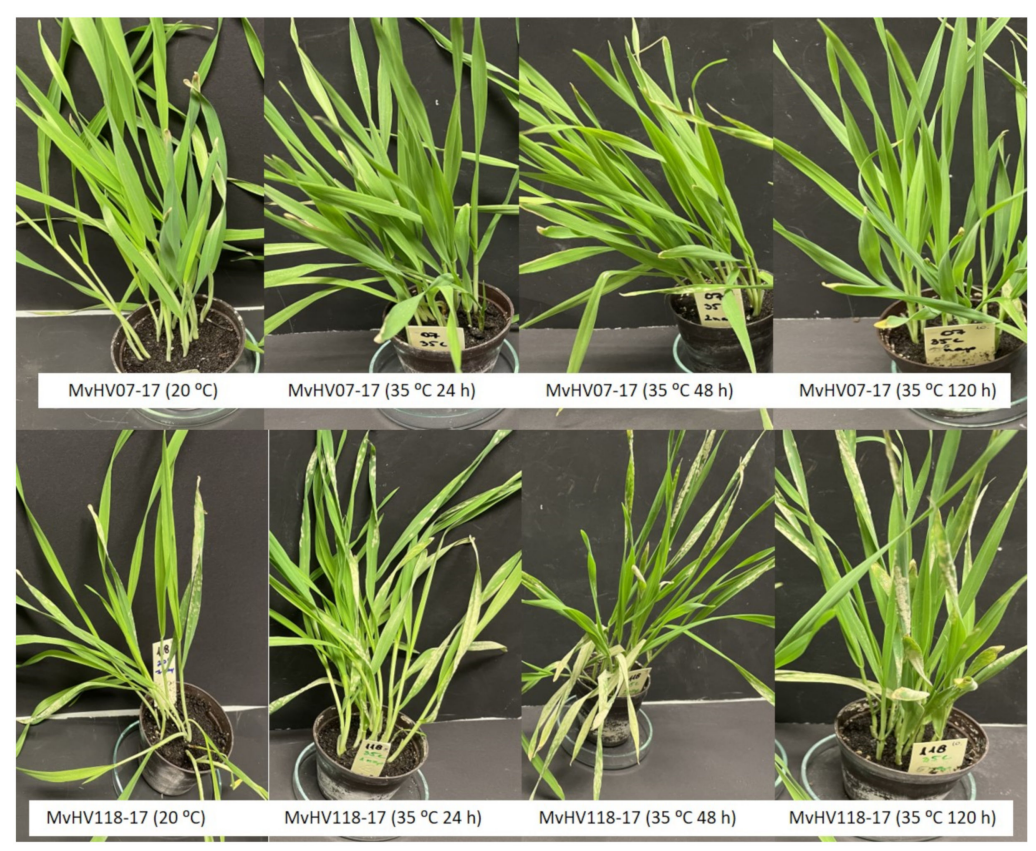

Figure 3. Powdery mildew (Blumeria graminis f. sp. hordei A6) symptoms in resistant (MvHV0717) and susceptible (MvHV118-17) genotypes of barley seven days after inoculation. Plants were pretreated with heat $\left(35^{\circ} \mathrm{C}\right)$ for $24 \mathrm{~h}, 48 \mathrm{~h}$ and $120 \mathrm{~h}$ before powdery mildew inoculation. Control plants were kept at $20^{\circ} \mathrm{C}$.

\subsection{Expression of Plant Defense/Stress Genes in Heat-Stressed and BGH-Infected Barley}

To assess the possible combined effects of heat stress and powdery mildew infection on the activities of stress/defense-associated genes (BAX inhibitor-1, Pathogenesis related 1-b and Respiratory burst oxidase homologue F2), we assayed their expression in both resistant and susceptible plants inoculated with powdery mildew and previously exposed to high temperatures. As controls, defense gene expression was also assayed in plants that received only heat treatment but no Bgh inoculation and inoculated plants that were held at an optimal temperature $\left(20^{\circ} \mathrm{C}\right)$. In the Bgh-inoculated susceptible line MvHV118-17 (S) held at $20^{\circ} \mathrm{C}$, the expression of $B A X$ inhibitor- 1 (HvBI-1) increased significantly one hour after inoculation and then gene expression was dropped to ca. half within $24 \mathrm{~h}$, as compared to the $0 \mathrm{~h}$ control. The expression of HvBI-1 in resistant MvHV07-17 (R) plants showed a similar trend as in the susceptible plants except that at $1 \mathrm{~h}$ we did not experience a significant increase in gene expression (Figure 4).

Long-term (24, 48 and $120 \mathrm{~h}$ ) heat stress significantly reduced the expression of $\mathrm{HvBI}-1$ in both lines at zero, one, two and six $\mathrm{h}$ after Bgh inoculation. The decrease in gene expression was detectable in both infected and uninfected plants (Figure 4). Interestingly, $24 \mathrm{~h}$ after inoculation, $\mathrm{HvBI}-1$ expression increased significantly only in the resistant line (MvHV07-17), regardless of infection, to levels comparable to HvBI-1 expression in control plants maintained at $20^{\circ} \mathrm{C}$ (Figure 4). A short-term heat shock (30 s) generally did not cause a marked decrease in gene expression; however, $24 \mathrm{~h}$ after heat stress and/or inoculation the expression of $H v B I-1$ in heat stressed or heat stressed and infected plants increased significantly in both resistant and susceptible lines (Figure 4). In the Bgh-inoculated, susceptible MvHV118-17 (S) line kept at $20^{\circ} \mathrm{C}$, the expression of Pathogenesis related 1- $b$ (HvPR1-b) overall did not change significantly during the first $24 \mathrm{~h}$ of infection; however, in the resistant line (MvHV07-17), the expression of HvPR1-b doubled as compared to the zero-hour plants (Figure 5). Heat stress significantly reduced the expression of HvPR1-b in both lines at all examined time points after HST (Figure 5). As the duration of heat stress increased, a dramatic suppression of $H v P R 1-b$ expression became clearly evident. While the 30-s heat stress reduced HvPR1- $b$ expression by only ca. half, the $120 \mathrm{~h}$ heat stress reduced expression to 1/100 of control levels (Figure 5). Remarkably, however, the reduced 
expression of HvPR1-b in heat-treated plants returned to normal or higher levels only in the infected resistant line (MvHV07-17), $24 \mathrm{~h}$ after heat stress and inoculation (Figure 5).

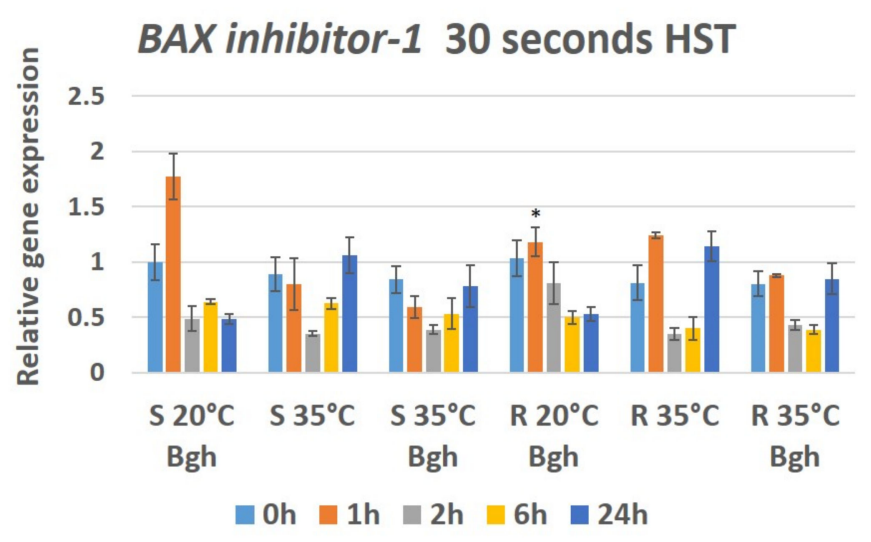

BAX inhibitor-1 48 hours HST

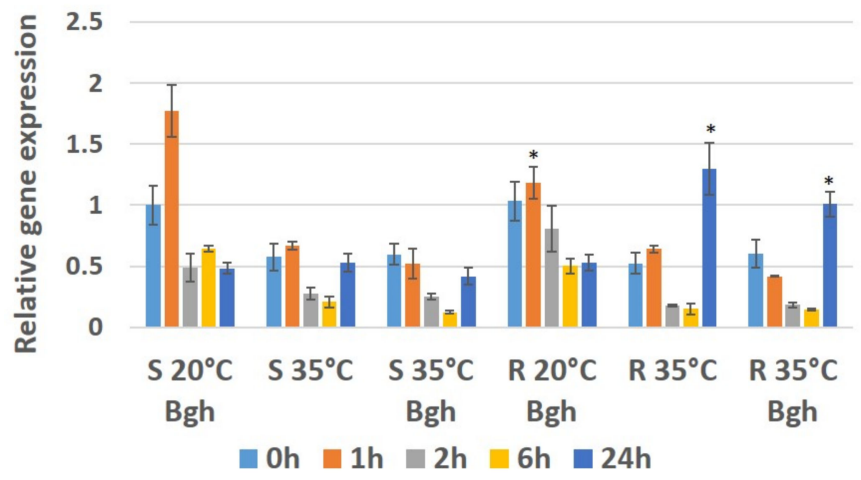

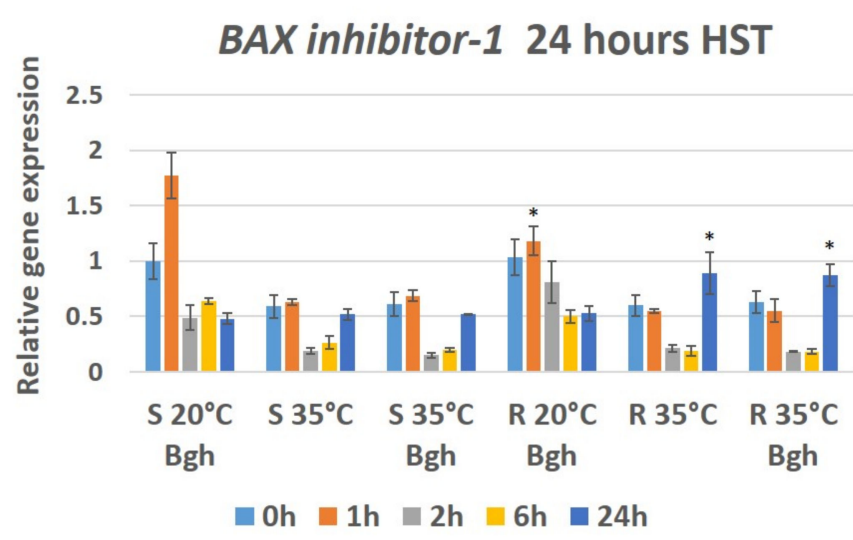

BAX inhibitor-1 120 hours HST

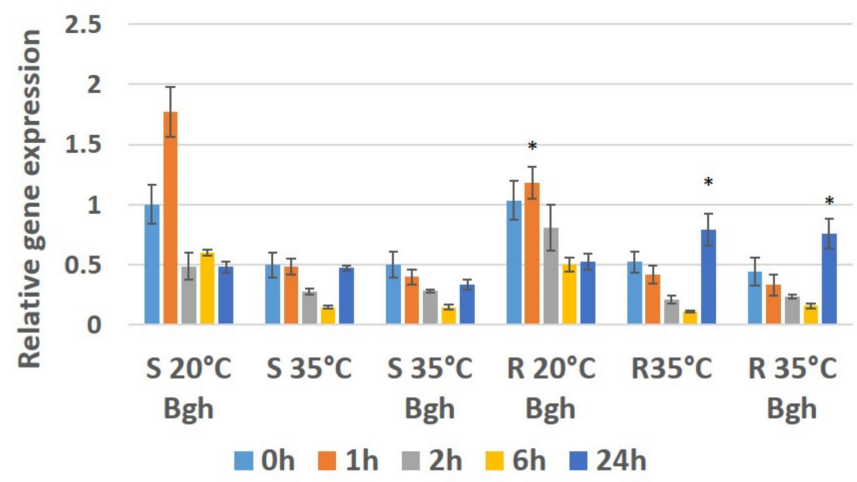

Figure 4. Expression of the barley BAX inhibitor-1 gene as detected by RT-qPCR in resistant MvHV07-17 (R) and susceptible MvHV118-17 (S) barley lines at early time points ( $0 \mathrm{~h}, 1 \mathrm{~h}, 2 \mathrm{~h}, 6 \mathrm{~h}$ and $24 \mathrm{~h}$ ) following powdery mildew (Bgh) inoculation. Heat shock treatments (HST) at $35^{\circ} \mathrm{C}$ for $30 \mathrm{~s}, 24 \mathrm{~h}, 48 \mathrm{~h}$ and $120 \mathrm{~h}$ were applied immediately before powdery mildew inoculation ( $\mathrm{R} 35^{\circ} \mathrm{C} \mathrm{Bgh}$ and S $35^{\circ} \mathrm{C} \mathrm{Bgh}$ ). Heat-treated but not inoculated (R $35^{\circ} \mathrm{C}$ and S $35^{\circ} \mathrm{C}$ ) and inoculated but not heat-treated plants ( $\mathrm{R} 20^{\circ} \mathrm{C}$ Bgh and S $20^{\circ} \mathrm{C} \mathrm{Bgh}$ ) were used as controls. The graphs show the average of three experiments. Error bars represent standard deviation. Asterisks $\left(^{*}\right)$ indicate statistically significant differences between resistant and susceptible lines for each specific treatment at $p<0.05$.

As mentioned before, short-term (30 s) HST reduced the expression of HvPR1-b; however, a $30 \mathrm{~s} \mathrm{HST}$ and Bgh inoculation together increased the expression of the gene at most investigated time points in both barley lines (Figure 5). In both the susceptible (MvHV118-17) and resistant (MvHV07-17) Bgh-inoculated lines held at $20^{\circ} \mathrm{C}$, the expression of $H v R B O H F 2$ was reduced 2, 6 and $24 \mathrm{~h}$ after inoculation (Figure 6). Interestingly, however, a $30 \mathrm{~s}$ HST induced HvRBOHF2 expression in both lines $24 \mathrm{~h}$ after HST but only in non-inoculated plants (Figure 6). Long-term (48 and $120 \mathrm{~h}$ ) HST significantly reduced the expression of HvRBOHF2 at $6 \mathrm{~h}$ after HST in both barley lines. However, after a $120 \mathrm{~h} \mathrm{HST}$, a reduced expression of $H v R B O H F 2$ was detectable both at 6 and at $24 \mathrm{~h}$ after treatments but primarily in the susceptible line upon Bgh inoculation (Figure 6). In resistant plants (MvHV07-17) heat-treated for $48 \mathrm{~h}, \mathrm{HvRBOHF} 2$ expression began to increase at $24 \mathrm{~h}$ after heat stress regardless of Bgh inoculation, a similar trend as seen with HvBI-1 (Figure 6). 
PR1-b 30 seconds HST

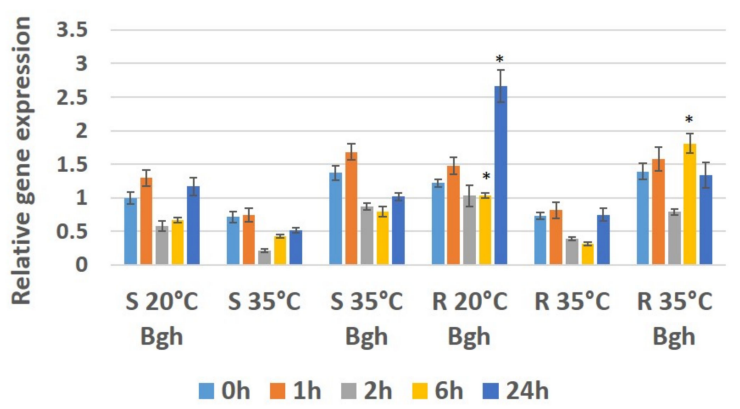

PR1-b 48 hours HST

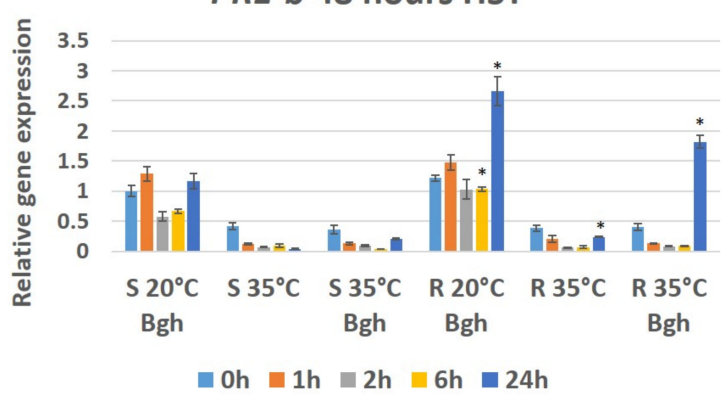

PR1-b 24 hours HST

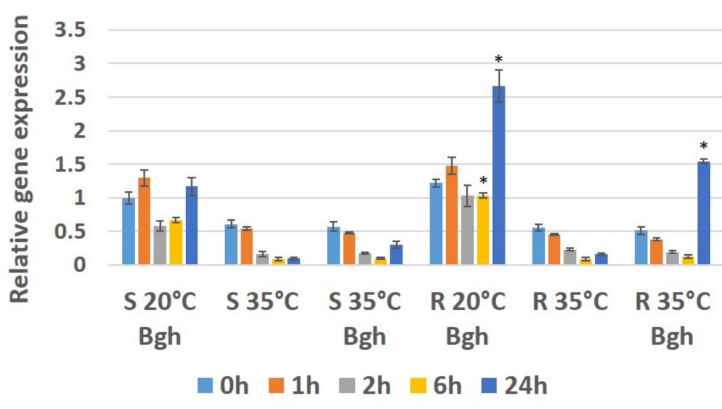

PR1-b 120 hours HST

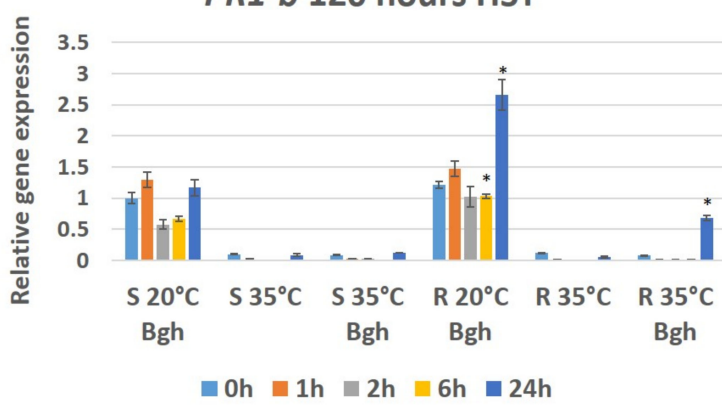

Figure 5. Expression of the barley Pathogenesis related-1b gene (PR1-b) as detected by RT-qPCR in resistant MvHV07-17 (R) and susceptible MvHV118-17 (S) barley lines at early time points ( $0 \mathrm{~h}, 1 \mathrm{~h}, 2 \mathrm{~h}, 6 \mathrm{~h}$ and $24 \mathrm{~h})$ following powdery mildew (Bgh) inoculation. Heat shock treatments (HST) at $35^{\circ} \mathrm{C}$ for $30 \mathrm{~s}, 24 \mathrm{~h}, 48 \mathrm{~h}$ and $120 \mathrm{~h}$ were applied immediately before powdery mildew inoculation ( $\mathrm{R} 35^{\circ} \mathrm{C}$ Bgh and $\mathrm{S} 35^{\circ} \mathrm{C}$ Bgh). Heat-treated but not inoculated (R $35^{\circ} \mathrm{C}$ and S $35^{\circ} \mathrm{C}$ ) and inoculated but not heat-treated plants $\left(\mathrm{R} 20^{\circ} \mathrm{C}\right.$ Bgh and S $\left.20^{\circ} \mathrm{C} \mathrm{Bgh}\right)$ were used as controls. The graphs show the average of three experiments. Error bars represent standard deviation. Asterisks $\left({ }^{*}\right)$ indicate statistically significant differences between resistant and susceptible lines for each specific treatment at $p<0.05$.

RBOHF2 30 seconds HST

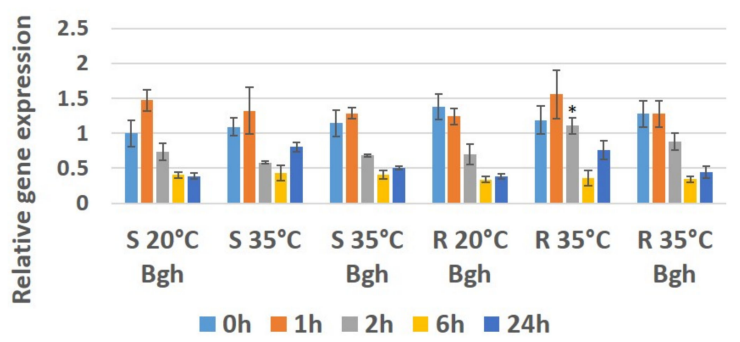

RBOHF2 48 hours HST

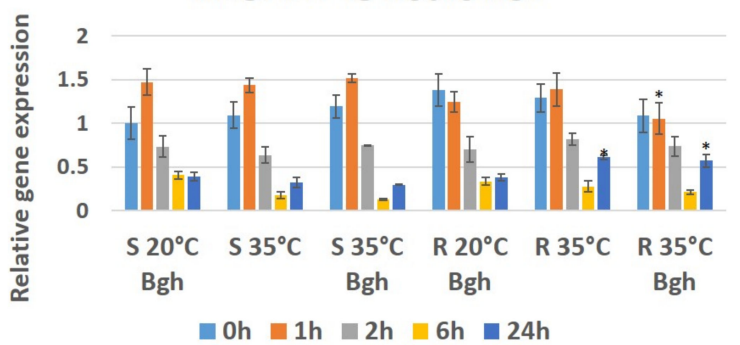

RBOHF2 24 hours HST

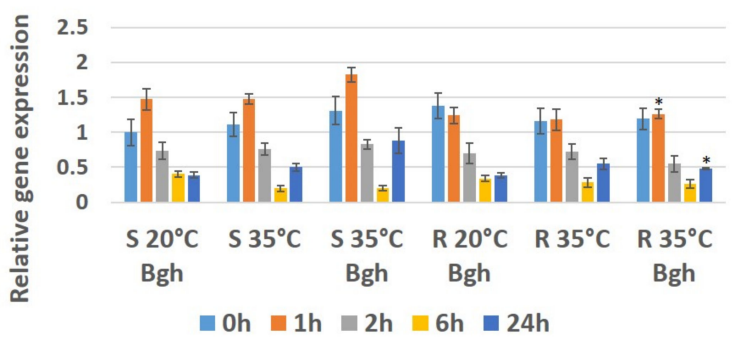

RBOHF2 120 hours HST

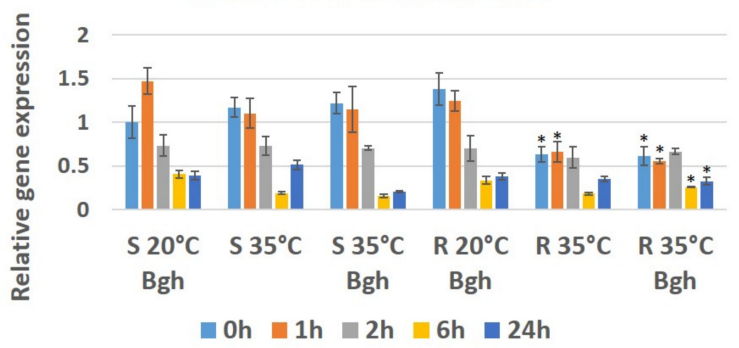

Figure 6. Expression of the barley Respiratory burst oxidase homologue F2 gene (RBOHF2) as detected by RT-qPCR in resistant MvHV07-17 (R) and susceptible MvHV118-17 (S) barley lines at early time points ( $0 \mathrm{~h}, 1 \mathrm{~h}, 2 \mathrm{~h}, 6 \mathrm{~h}$ and $24 \mathrm{~h})$ following powdery mildew (Bgh) inoculation. Heat shock treatments (HST) at $35^{\circ} \mathrm{C}$ for $30 \mathrm{~s}, 24 \mathrm{~h}, 48 \mathrm{~h}$ and $120 \mathrm{~h}$ were applied immediately before powdery mildew inoculation ( $\mathrm{R} 35^{\circ} \mathrm{C}$ Bgh and S $35^{\circ} \mathrm{C}$ Bgh). Heat-treated but not inoculated (R $35^{\circ} \mathrm{C}$ and $\mathrm{S} 35^{\circ} \mathrm{C}$ ) and inoculated but not heat-treated plants ( $\mathrm{R} 20^{\circ} \mathrm{C} \mathrm{Bgh}$ and S $20^{\circ} \mathrm{C} \mathrm{Bgh}$ ) were used as controls. The graphs show the average of three experiments. Error bars represent standard deviation. Asterisks $\left.{ }^{*}\right)$ indicate statistically significant differences between resistant and susceptible lines for each specific treatment at $p<0.05$. 


\section{Discussion}

Heat stress may significantly influence plant-pathogen interactions. To our knowledge, this is the first report showing that pre-exposure of powdery mildew-susceptible barley (MvHV118-17) to a prolonged $(24,48,120 \mathrm{~h}$ ) heat stress enhances susceptibility to the powdery mildew Blumeria graminis f. sp hordei (Bgh), manifested as both increased symptom severity and pathogen levels. Remarkably, in the resistant barley line (MvHV07-17), heat stress had no significant effect on either symptoms or pathogen levels; only the longest duration of high temperature stress $\left(120 \mathrm{~h}\right.$ at $\left.35^{\circ} \mathrm{C}\right)$ caused a marginal increase in pathogen levels, suggesting that resistance of MvHV07-17 to Bgh could be durable even under field conditions. However, previous studies demonstrate that prolonged heat stress often suppresses plant disease resistance to various pathogens, likely due to heat-induced conformation changes in the protein products of plant resistance/defense genes [23,34,46-51]. It remains to be elucidated whether the effective Bgh resistance of MvHV07-17 barley is due to efficient repair or evasion of conformational changes in resistance and defenserelated proteins.

The role of short-term (from $30 \mathrm{~s}$ to $2 \mathrm{~h}$ ) heat stress in modulating powdery mildew resistance in cereals had been studied previously. A short-term heat shock (30-40 s at $50{ }^{\circ} \mathrm{C}$ ) followed by immediate Bgh inoculation significantly reduced powdery mildew infection in susceptible barley $[37,38]$ similar to our results, where a $30 \mathrm{~s}$ heat shock at 28 and $35^{\circ} \mathrm{C}$ also significantly reduced Bgh accumulation in susceptible MvHV118-17. On the contrary, others have shown that a short term exposure to high temperature, e.g., submerging plants in $49{ }^{\circ} \mathrm{C}$ water for $20 \mathrm{~s}$, increased susceptibility of near-isogenic barley lines to Bgh. In genetically susceptible barley, the heat-shock further increased susceptibility, while in powdery mildew resistant barley lines resistance was converted into susceptibility [35]. In this case, however, Bgh inoculation was administered one day after heat-shock, as opposed to our work and previous studies, where heat shock was directly followed by inoculation $[37,38]$. It seems that the time elapsed between heat shock and Bgh inoculation is an important factor in determining the final outcome of infection (resistance vs. susceptibility) that could explain the different results of the above mentioned studies. In barley, Schwarzbach [39] has shown that exposure to a high temperature $\left(36^{\circ} \mathrm{C}\right.$ for $30 \mathrm{~min}, 60 \mathrm{~min}$ and $120 \mathrm{~min}$ durations) causes enhanced susceptibility to Bgh in both genetically resistant $(\mathrm{mlo})$ and susceptible barley cultivars [39]. In contrast, we found that exposure of barley to $35^{\circ} \mathrm{C}$ for 60 or $120 \mathrm{~min}$ did not cause any significant effect on Bgh symptoms or biomass in both lines 7 days after inoculation. Importantly, in order to better simulate field conditions, we used intact barley plants in our assays, as opposed to the study of Schwarzbach [39], where leaf segments on agar medium were employed, a possible cause of differential reactions of heat-stressed barley $\left(35-36^{\circ} \mathrm{C}\right.$ for $\left.30-120 \mathrm{~min}\right)$ to powdery mildew infection.

Our results show that the expression of three plant defense-related genes ( $B A X$ inhibitor-1, Pathogenesis related 1-b and Respiratory burst oxidase homologue F2) is repressed drastically during prolonged (24, 48 and $120 \mathrm{~h}$ ) heat stress. Interestingly, however, the expression of BAX inhibitor-1 and Respiratory burst oxidase homologue F2 is quickly restored (24 h after heat stress) in the resistant plants regardless of Bgh infection but not in the susceptible barley line. Furthermore, repression of the Pathogenesis related 1-b gene was also reactivated after heat stress but only in Bgh-inoculated resistant plants.

BAX Inhibitor-1 (BI-1) is a programmed cell death (PCD) suppressor in eukaryotes [52,53]. Arabidopsis BI mutants show increased sensitivity to heat shock-induced cell death; however, the mutants were indistinguishable from wild-type plants under normal growth conditions [54]. Furthermore, overexpressing the pepper (Capsicum annuum L.) gene CaBI-1 in tobacco (Nicotiana tabacum L.) markedly improved tolerance to high temperature, water deficit, and high salinity in transgenic plants [55]. It can be assumed that heat stress induced PCD in Bgh-resistant barley (MvHV07-17) is inhibited by HvBI-1 which is reactivated only in this line within $24 \mathrm{~h}$ after the heat shock. Although $\mathrm{HvBI}-1$ expression was enhanced after powdery mildew inoculation in different barley lines, 
HvBI-1 expression was most pronounced in resistant genotypes (Mla12, Mlg) undergoing a hypersensitive resistance (HR) associated with PCD [56]. These authors hypothesized that BI-1 is suppressing cell death in plant tissues mounting an HR after fungal attack [56]. Furthermore, it was shown that barley BI-1 is a Bgh susceptibility factor, an effect likely caused by PCD suppression, since powdery mildews are biotrophic pathogens that prefer live host tissues for efficient infection [57-59]. Our results showed that the resistant MvHV07-17 barley kept at optimal temperatures $\left(20^{\circ} \mathrm{C}\right)$ did not show any visible HR symptoms after Bgh inoculation. Presumably, no HR (PCD) develops and therefore an increase in HvBI-1 expression is not detectable in infected plants. However, BI-1 may have a role not only in PCD-inhibition but-at least in certain plant-pathogen interactions-in disease resistance per se, which has been shown to be the case in wheat, where silencing of BI-1 resulted in converting an HR-type resistance to the rust pathogen Puccinia striiformis $\mathrm{f}$. sp. tritici to partial susceptibility [60]. Furthermore, silencing of BI-1 in N. benthamiana enhanced systemic accumulation of Potato virus $X$ and Potato virus $Y$ [61]. Nevertheless, our results suggest that enhanced HvBI-1 expression in the Bgh-resistant barley line MvHV07-17 has a role primarily in alleviating heat stress and PCD, rather than influencing pathogen resistance.

Prolonged heat stress reduced expression of the barley Respiratory burst oxidase homologue F2 gene (HvRBOHF2) primarily in the susceptible line, while HvRBOHF2 expression was more or less restored ( $24 \mathrm{~h}$ after heat stress) in resistant plants, regardless of Bgh inoculation. $\mathrm{RBOH}$ genes encode plasma membrane proteins with NADPH-oxidase activity and $\mathrm{RBOH}$-dependent reactive oxygen species (ROS) generation is associated with pathogen recognition during the oxidative burst [62]. Transgenic barley HvRBOHF2-knock down seedlings were much more susceptible to penetration caused by Bgh $[43,63]$, pointing to the role of $H v R B O H F 2$ in barley Bgh resistance. Interestingly, suppression of resistance to Tobacco mosaic virus (TMV) at higher temperatures $\left(30^{\circ} \mathrm{C}\right)$ is also correlated with reduced ROS generation and down-regulation of expression of $N t R B O H D$, a tobacco functional homolog of HvRBOHF2 [64]. This suggests that a reduced expression of HvRBOHF2 in the barley line MvHV118-17 exposed to prolonged heat stress may underpin not only Bgh-susceptibility but also heat sensitivity. Indeed, transcript levels of ROS-producing $R B O H$ genes decrease in response to heat $\left(42^{\circ} \mathrm{C}\right)$ in Arabidopsis [65]. Importantly, the activity of $\mathrm{RBOH}$-encoded NADPH-oxidases have a dual role during abiotic and biotic stresses by producing ROS and initiating PCD in infected/stressed plant cells and simultaneously limiting the spread of cell death in adjacent cells by, e.g., activating antioxidant enzymes [7,8]. Accordingly, an increased NADPH-oxidase activity $24 \mathrm{~h}$ after powdery mildew infection is correlated with a symptomless (i.e., suppressed PCD) nonhost resistance of barley to B. graminis $\mathrm{f}$. sp. tritici, suggesting that barley $R B O H$ genes may confer both pathogen resistance and PCD limitation [36]. In fact, HvRBOHF2 has been shown to negatively regulate PCD in Bgh-infected, older (17 day-old) barley leaves, while conferring Bgh resistance primarily in younger (11 day-old) leaves [63]. Therefore, a suppressed HvRBOHF2 transcription in the Bgh-susceptible MvHV118-17 barley may indeed contribute to increased sensitivity to heat stress-induced PCD while also conferring Bgh susceptibility.

The activation of PR1 genes and accumulation of their protein products in plants during pathogen attack is well-known [13]. Enhanced expression of different $P R$ genes including PR1 is induced in resistant wheat plants infected with powdery mildew but not in susceptible cultivars [66]. Moreover, plant PR1 proteins have sterol binding activity and hindering fungal sterol biosynthesis can be also potentially effective against powdery mildew fungi [13]. It is known that the barley PR1-b protein contributes to penetration resistance to $\mathrm{Bgh}$, since transient silencing of $P R 1-b$ increases penetration efficiency of the pathogen in attacked epidermal cells [12]. Furthermore, another PR protein, PR17c is also required for penetration resistance of barley to powdery mildew [67]. A Bgh effector candidate, CSEP0055 interacts with barley PR1-b and PR17c leading to enhanced virulence, indicating a possible suppression of these PR proteins by Bgh [67]. In the present study, we have shown that a prolonged heat stress drastically reduces the expression of $H v P R 1-b$ in both resistant and susceptible barley lines. However, the resistant line (MvHV07-17) 
retained its ability to defend itself against Bgh even following a pre-exposure to high temperatures $\left(35^{\circ} \mathrm{C}\right)$, possibly, at least in part, by the rapid recovery of HvPR1- $b$ gene expression in Bgh-infected plants, which confirms the role of barley PR1-b as a pivotal component of powdery mildew resistance.

\section{Conclusions}

We found that pre-exposure to a prolonged heat stress $\left(35^{\circ} \mathrm{C}\right.$ for 24,48 and $120 \mathrm{~h}$ ) enhances powdery mildew infection in the susceptible barley line MvHV118-17. This suggests that with an increased likelihood of sustained high temperatures under field conditions, an increased damage caused by powdery mildew infection of, e.g., cereals like barley can be expected. In contrast, we found that a powdery mildew resistant barley line (MvHV07-17) retained its resistance even at high temperatures, since only an exposure to $35^{\circ} \mathrm{C}$ for $120 \mathrm{~h}$ could induce a marginal increase in powdery mildew biomass. Importantly, even such a mild perturbation of pathogen resistance in a genetically resistant crop line following a prolonged exposure to high temperatures may potentially contribute to an epidemic by providing an additional inoculum source in the field. Therefore, an important task for plant breeders should be to investigate any possible changes in pathogen (e.g., powdery mildew) resistance of a given crop line/cultivar in response to prolonged heat stress. In order to address this problem, plant breeding for tolerance to combined (i.e., abiotic and biotic) stresses will be a pivotal task in the near future. In fact, the powdery mildew resistant barley line used in this study (MvHV07-17) has been shown to exhibit enhanced drought tolerance, as compared to the susceptible line MvHV118-17 [68]. To create crop cultivars that simultaneously evade abiotic stresses (e.g., high temperature, drought) and resist pathogen infections, two key approaches to consider are: (1) introgression of defense related genes from wild species via conventional breeding or genetic engineering [69], and (2) isolating mutants that retain disease resistance during exposure to abiotic stresses like heat [50]. Therefore, deciphering temperature-sensitive defense mechanisms and identifying novel, robust plant resistance pathways will be likely one of the most important weapons against plant pathogens to minimize crop yield losses in response to global warming [23].

Author Contributions: Conceptualization, A.K. and L.K.; Methodology, A.K., L.K., K.M., J.B., V.K. and I.S.; Investigation, I.S., J.K.N., A.K. and L.K.; Data analysis and interpretation, A.K., L.K. and J.F.; Writing-review and editing, I.S., J.K.N., K.M., J.B., V.K., A.K. and L.K.; Visualization, I.S., A.K. and J.F.; Supervision, A.K. and L.K.; Project administration, A.K.; Funding acquisition, A.K.; All authors have read and agreed to the published version of the manuscript.

Funding: This research was funded by the Hungarian National Research, Development and Innovation Office, Grant Numbers: NKFIH FK131401 and K119276. The APC was funded by NKFIH FK131401.

Institutional Review Board Statement: Not applicable.

Informed Consent Statement: Not applicable.

Data Availability Statement: Not applicable.

Acknowledgments: The barley (H. vulgare) cv. Ingrid Mlo and race A6 of barley powdery mildew (B. graminis f. sp. hordei) were kindly supplied by Karl-Heinz Kogel (Justus Liebig University, Giessen, Germany).

Conflicts of Interest: The authors declare no conflict of interest. The funders had no role in the design of the study; in the collection, analyses, or interpretation of data; in the writing of the manuscript, or in the decision to publish the results.

\section{References}

1. Jones, J.D.G.; Dangl, J.L. The plant immune system. Nature 2006, 444, 323-329. [CrossRef]

2. Boller, T.; Felix, G. A renaissance of elicitors: Perception of microbe-associated molecular patterns and danger signals by pattern-recognition receptors. Annu. Rev. Plant Biol. 2009, 60, 379-407. [CrossRef] 
3. Dangl, J.L.; Horvath, D.M.; Staskawicz, B.J. Pivoting the plant immune system from dissection to deployment. Science 2013, 341, 746-751. [CrossRef]

4. Hammond-Kosack, K.E.; Jones, J.D.G. Plant disease resistance genes. Annu. Rev. Plant Physiol. Plant Mol. Biol. 1997, 48, 575-607. [CrossRef]

5. Levine, A.; Tenhaken, R.; Dixon, R.; Lamb, C. $\mathrm{H}_{2} \mathrm{O}_{2}$ from the oxidative burst orchestrates the plant hypersensitive disease resistance response. Cell 1994, 79, 583-593. [CrossRef]

6. Thordal-Christensen, H.; Zhang, Z.; Wei, Y.; Collinge, D.B. Subcellular localization of $\mathrm{H}_{2} \mathrm{O}_{2}$ in plants. $\mathrm{H}_{2} \mathrm{O}_{2}$ accumulation in papillae and hypersensitive response during the barley-powdery mildew interaction. Plant J. 1997, 11, 1187-1194. [CrossRef]

7. Torres, M.A.; Jones, J.D.G.; Dangl, J.L. Pathogen-induced, NADPH oxidase-derived reactive oxygen intermediates suppress spread of cell death in Arabidopsis thaliana. Nat. Genet. 2005, 37, 1130-1134. [CrossRef]

8. Pogány, M.; von Rad, U.; Grün, S.; Dongó, A.; Pintye, A.; Simoneau, P.; Bahnweg, G.; Kiss, L.; Barna, B.; Durner, J. Dual roles of reactive oxygen species and NADPH oxidase RBOHD in an Arabidopsis-Alternaria pathosystem. Plant Physiol. 2009, 151, 1459-1475. [CrossRef]

9. Hafez, Y.M.; Bacsó, R.; Király, Z.; Künstler, A.; Király, L. Up-regulation of antioxidants in tobacco by low concentrations of $\mathrm{H}_{2} \mathrm{O}_{2}$ suppresses necrotic disease symptoms. Phytopathology 2012, 102, 848-856. [CrossRef]

10. Van Loon, L.C.; Rep, M.; Pieterse, C.M.J. Significance of inducible defense-related proteins in infected plants. Annu. Rev. Phytopathol. 2006, 44, 135-162. [CrossRef]

11. Sels, J.; Mathys, J.; De Coninck, B.M.A.; Cammue, B.P.A.; De Bolle, M.F.C. Plant pathogenesis-related (PR) proteins: A focus on PR peptides. Plant Physiol. Biochem. 2008, 46, 941-950. [CrossRef] [PubMed]

12. Schultheiss, H.; Dechert, C.; Király, L.; Fodor, J.; Michel, K.; Kogel, K.H.; Hückelhoven, R. Functional assessment of the pathogenesis-related protein PR-1b in barley. Plant Sci. 2003, 165, 1275-1280. [CrossRef]

13. Breen, S.; Williams, S.J.; Outram, M.; Kobe, B.; Solomon, P.S. Emerging insights into the functions of pathogenesis-related protein 1. Trends Plant Sci. 2017, 22, 871-879. [CrossRef]

14. Glawe, D.A. The powdery mildews: A review of the world's most familiar (yet poorly known) plant pathogens. Annu. Rev. Phytopathol. 2008, 46, 27-51. [CrossRef]

15. Braun, U. The current systematics and taxonomy of the powdery mildews (Erysiphales): An overview. Mycoscience 2011, 52, 210-212. [CrossRef]

16. Oliver, R.; Hewitt, H.G. Fungicides in Crop Protection, 2nd ed.; Oliver, R., Hewitt, H.G., Eds.; CABI: Wallingford, UK, 2014.

17. Dean, R.; van Kan, J.A.L.; Pretorius, Z.A.; Hammond-Kosack, K.E.; Di Pietro, A.; Spanu, P.D.; Rudd, J.J.; Dickman, M.; Kahmann, R.; Ellis, J.; et al. The Top 10 fungal pathogens in molecular plant pathology. Mol. Plant Pathol. 2012, 13, 414-430. [CrossRef]

18. Hacquard, S.; Kracher, B.; Maekawa, T.; Vernaldi, S.; Schulze-Lefert, P.; van Themaat, E.V.L. Mosaic genome structure of the barley powdery mildew pathogen and conservation of transcriptional programs in divergent hosts. Proc. Natl. Acad. Sci. USA 2013, 110, E2219-E2228. [CrossRef]

19. Cantalapiedra, C.P.; García-Pereira, M.J.; Gracia, M.P.; Igartua, E.; Casas, A.M.; Contreras-Moreira, B. Large differences in gene expression responses to drought and heat stress between elite barley cultivar scarlett and a Spanish landrace. Front. Plant Sci. 2017, 8. [CrossRef]

20. Challinor, A.J.; Watson, J.; Lobell, D.B.; Howden, S.M.; Smith, D.R.; Chhetri, N. A meta-analysis of crop yield under climate change and adaptation. Nat. Clim. Chang. 2014, 4, 287-291. [CrossRef]

21. Lasram, A.; Masmoudi, M.M.; Mechlia, N.B. Effect of high temperature stress on wheat and barley production in Northern Tunisia. In Water and Land Security in Drylands, Response to Climate Change; Ouessar, M., Gabriels, D., Tsunekawa, A., Evett, S., Eds.; Springer: Cham, Switzerland, 2017; pp. 27-34.

22. Driedonks, N.; Xu, J.; Peters, J.L.; Park, S.; Rieu, I. Multi-level interactions between heat shock factors, heat shock proteins, and the redox system regulate acclimation to heat. Front. Plant Sci. 2015, 6, 999. [CrossRef] [PubMed]

23. Desaint, H.; Aoun, N.; Deslandes, L.; Vailleau, F.; Roux, F.; Berthomé, R. Fight hard or die trying: When plants face pathogens under heat stress. New Phytol. 2021, 229, 712-734. [CrossRef]

24. Matić, S.; Cucu, M.A.; Garibaldi, A.; Gullino, M.L. Combined effect of $\mathrm{CO}_{2}$ and temperature on wheat powdery mildew development. Plant Pathol. J. 2018, 34, 316-326. [CrossRef] [PubMed]

25. McDonald, B.A.; Stukenbrock, E.H. Rapid emergence of pathogens in agro-ecosystems: Global threats to agricultural sustainability and food security. Philos. Trans. R. Soc. B Biol. Sci. 2016, 371, 20160026. [CrossRef] [PubMed]

26. Atkinson, N.J.; Urwin, P.E. The interaction of plant biotic and abiotic stresses: From genes to the field. J. Exp. Bot. 2012, 63, 3523-3544. [CrossRef]

27. Suzuki, N.; Rivero, R.M.; Shulaev, V.; Blumwald, E.; Mittler, R. Abiotic and biotic stress combinations. New Phytol. 2014, 203 , 32-43. [CrossRef]

28. Onaga, G.; Wydra, K.; Koopmann, B.; Chebotarov, D.; Séré, Y.; Von Tiedemann, A. High temperature effects on Pi54 conferred resistance to Magnaporthe oryzae in two genetic backgrounds of Oryza sativa. J. Plant Physiol. 2017, 212, 80-93. [CrossRef] [PubMed]

29. Sharma, R.C.; Duveiller, E.; Ortiz-Ferrara, G. Progress and challenge towards reducing wheat spot blotch threat in the Eastern Gangetic Plains of South Asia: Is climate change already taking its toll? Field Crop. Res. 2007, 103, 109-118. [CrossRef] 
30. Aust, H.; Hoyningen-Huene, J.V. Microclimate in relation to epidemics of powdery mildew. Annu. Rev. Phytopathol. 1986, 24, 491-510. [CrossRef]

31. Ward, S.V.; Manners, J.G. Environmental effects on the quantity and viability of conidia produced by Erysiphe graminis. Trans. Br. Mycol. Soc. 1974, 62, 119-128. [CrossRef]

32. Akai, S. Relation of temperature to the invasion of the barley powdery mildew into host. Agric. Hortic. Tokyo 1952, $27,1135$.

33. Jenkyn, J.F.; Bainbridge, A. Biology and pathology of cereal powdery mildews. In The Powdery Mildews; Spencer, D.M., Ed.; Academic Press: London, UK, 1978; pp. 283-321.

34. Wang, Y.; Bao, Z.; Zhu, Y.; Hua, J. Analysis of temperature modulation of plant defense against biotrophic microbes. Mol. Plant-Microbe Interact. 2009, 22, 498-506. [CrossRef]

35. Barna, B.; Harrach, B.D.; Viczián, O.; Fodor, J. Heat induced susceptibility of barley lines with various types of resistance genes to powdery mildew. Acta Phytopathol. Entomol. Hung. 2014, 49, 177-188. [CrossRef]

36. Künstler, A.; Bacsó, R.; Albert, R.; Barna, B.; Király, Z.; Hafez, Y.M.; Fodor, J.; Schwarczinger, I.; Király, L. Superoxide $\left(\mathrm{O}_{2}{ }^{-}\right.$) accumulation contributes to symptomless (type I) nonhost resistance of plants to biotrophic pathogens. Plant Physiol. Biochem. 2018, 128, 115-125. [CrossRef] [PubMed]

37. Schweizer, P.; Vallélian-Bindschedler, L.; Mösinger, E. Heat-induced resistance in barley to the powdery mildew fungus Erysiphe graminis f. sp. hordei. Physiol. Mol. Plant Pathol. 1995, 47, 51-66. [CrossRef]

38. Vallélian-Bindschedler, L.; Schweizer, P.; Mösinger, E.; Métraux, J.P. Heat-induced resistance in barley to powdery mildew (Blumeria graminis f. sp. hordei) is associated with a burst of active oxygen species. Physiol. Mol. Plant Pathol. 1998, 52, 185-199. [CrossRef]

39. Schwarzbach, E. Heat induced susceptibility of mlo-barley to powdery mildew (Blumeria graminis D.C. f. sp. hordei Marchal). Czech J. Genet. Plant Breed. 2001, 37, 82-87.

40. Höller, K.; Király, L.; Künstler, A.; Müller, M.; Gullner, G.; Fattinger, M.; Zechmann, B. Enhanced glutathione metabolism is correlated with sulfur-induced resistance in Tobacco mosaic virus-infected genetically susceptible Nicotiana tabacum plants. Mol. Plant-Microbe Interact. 2010, 23, 1448-1459. [CrossRef] [PubMed]

41. Trujillo, M.; Altschmied, L.; Schweizer, P.; Kogel, K.H.; Hückelhoven, R. Respiratory burst oxidase homologue A of barley contributes to penetration by the powdery mildew fungus Blumeria graminis f. sp. hordei. J. Exp. Bot. 2006, 57, 3781-3791. [CrossRef]

42. Eichmann, R.; Bischof, M.; Weis, C.; Shaw, J.; Lacomme, C.; Schweizer, P.; Duchkov, D.; Hensel, G.; Kumlehn, J.; Hückelhoven, R. BAX INHIBITOR-1 is required for full susceptibility of barley to powdery mildew. Mol. Plant-Microbe Interact. 2010, 23, 1217-1227. [CrossRef]

43. Proels, R.K.; Oberhollenzer, K.; Pathuri, I.P.; Hensel, G.; Kumlehn, J.; Hückelhoven, R. RBOHF2 of barley is required for normal development of penetration resistance to the parasitic fungus Blumeria graminis f. sp. hordei. Mol. Plant-Microbe Interact. 2010, 23, 1143-1150. [CrossRef] [PubMed]

44. Pennington, H.G.; Li, L.; Spanu, P.D. Identification and selection of normalization controls for quantitative transcript analysis in Blumeria graminis. Mol. Plant Pathol. 2016, 17, 625-633. [CrossRef] [PubMed]

45. Schmittgen, T.D.; Livak, K.J. Analyzing real-time PCR data by the comparative CT method. Nat. Protoc. 2008, 3, 1101-1108. [CrossRef] [PubMed]

46. Samuel, G. Some experiments on inoculating methods with plant viruses, and on local lesions. Ann. Appl. Biol. 1931, 18, 494-507. [CrossRef]

47. Moury, B.; Gebre Selassie, K.; Marchoux, G.; Daubèze, A.M.; Palloix, A. High temperature effects on hypersensitive resistance to Tomato spotted wilt tospovirus (TSWV) in pepper (Capsicum chinense Jacq.). Eur. J. Plant Pathol. 1998, 104, 489-498. [CrossRef]

48. Marathe, R.; Anandalakshmi, R.; Liu, Y.; Dinesh-Kumar, S.P. The Tobacco mosaic virus resistance gene. Mol. Plant Pathol. 2002, 3, 167-172. [CrossRef] [PubMed]

49. Liu, Y.; Burch-Smith, T.; Schiff, M.; Feng, S.; Dinesh-Kumar, S.P. Molecular chaperone Hsp90 associates with resistance protein N and its signaling proteins SGT1 and Rar1 to modulate an innate immune response in plants. J. Biol. Chem. 2004, 279, $2101-2108$. [CrossRef]

50. Zhu, Y.; Qian, W.; Hua, J. Temperature modulates plant defense responses through NB-LRR proteins. PLoS Pathog. 2010, 6, e1000844. [CrossRef]

51. Menna, A.; Nguyen, D.; Guttman, D.S.; Desveaux, D. Elevated temperature differentially influences effector-triggered immunity outputs in Arabidopsis. Front. Plant Sci. 2015, 6. [CrossRef] [PubMed]

52. Hückelhoven, R. BAX Inhibitor-1, an ancient cell death suppressor in animals and plants with prokaryotic relatives. Apoptosis 2004, 9, 299-307. [CrossRef] [PubMed]

53. Watanabe, N.; Lam, E. Bax Inhibitor-1, a conserved cell death suppressor, is a key molecular switch downstream from a variety of biotic and abiotic stress signals in plants. Int. J. Mol. Sci. 2009, 10, 3149-3167. [CrossRef]

54. Watanabe, N.; Lam, E. Arabidopsis Bax inhibitor-1 functions as an attenuator of biotic and abiotic types of cell death. Plant J. 2006, 45, 884-894. [CrossRef] [PubMed]

55. Isbat, M.; Zeba, N.; Kim, S.R.; Hong, C.B. A BAX inhibitor-1 gene in Capsicum annuum is induced under various abiotic stresses and endows multi-tolerance in transgenic tobacco. J. Plant Physiol. 2009, 166, 1685-1693. [CrossRef] [PubMed] 
56. Hückelhoven, R.; Dechert, C.; Trujillo, M.; Kogel, K.-H. Differential expression of putative cell death regulator genes in nearisogenic, resistant and susceptible barley lines during interaction with the powdery mildew fungus. Plant Mol. Biol. 2001, 47, 739-748. [CrossRef]

57. Hückelhoven, R.; Dechert, C.; Kogel, K.-H. Overexpression of barley BAX inhibitor 1 induces breakdown of $m l o-m e d i a t e d$ penetration resistance to Blumeria graminis. Proc. Natl. Acad. Sci. USA 2003, 100, 5555-5560. [CrossRef]

58. Eichmann, R.; Dechert, C.; Kogel, K.H.; Hückelhoven, R. Transient over-expression of barley BAX Inhibitor-1 weakens oxidative defence and MLA12-mediated resistance to Blumeria graminis f.sp. hordei. Mol. Plant Pathol. 2006, 7, 543-552. [CrossRef] [PubMed]

59. Babaeizad, V.; Imani, J.; Kogel, K.H.; Eichmann, R.; Hückelhoven, R. Over-expression of the cell death regulator BAX inhibitor-1 in barley confers reduced or enhanced susceptibility to distinct fungal pathogens. Theor. Appl. Genet. 2009, 118, 455-463. [CrossRef] [PubMed]

60. Wang, X.; Tang, C.; Huang, X.; Li, F.; Chen, X.; Zhang, G.; Sun, Y.; Han, D.; Kang, Z. Wheat BAX inhibitor-1 contributes to wheat resistance to Puccinia striiformis. J. Exp. Bot. 2012, 63, 4571-4584. [CrossRef] [PubMed]

61. Gaguancela, O.A.; Źuñiga, L.P.; Arias, A.V.; Halterman, D.; Flores, F.J.; Johansen, I.E.; Wang, A.; Yamaji, Y.; Verchot, J. The IRE1/bZIP60 pathway and Bax inhibitor 1 suppress systemic accumulation of potyviruses and potexviruses in Arabidopsis and Nicotiana benthamiana plants. Mol. Plant-Microbe Interact. 2016, 29, 750-766. [CrossRef]

62. Marino, D.; Dunand, C.; Puppo, A.; Pauly, N. A burst of plant NADPH oxidases. Trends Plant Sci. 2012, 17, 9-15. [CrossRef]

63. Torres, D.P.; Proels, R.K.; Schempp, H.; Hückelhoven, R. Silencing of RBOHF2 causes leaf age-dependent accelerated senescence, salicylic acid accumulation, and powdery mildew resistance in barley. Mol. Plant-Microbe Interact. 2017, 30, 906-918. [CrossRef]

64. Király, L.; Hafez, Y.M.; Fodor, J.; Király, Z. Suppression of Tobacco mosaic virus-induced hypersensitive-type necrotization in tobacco at high temperature is associated with downregulation of NADPH oxidase and superoxide and stimulation of dehydroascorbate reductase. J. Gen. Virol. 2008, 89, 799-808. [CrossRef] [PubMed]

65. Babbar, R.; Karpinska, B.; Grover, A.; Foyer, C.H. Heat-induced oxidation of the nuclei and cytosol. Front. Plant Sci. 2021, 11, 2184. [CrossRef] [PubMed]

66. Xin, M.; Wang, X.; Peng, H.; Yao, Y.; Xie, C.; Han, Y.; Ni, Z.; Sun, Q. Transcriptome comparison of susceptible and resistant wheat in response to powdery mildew infection. Genom. Proteom. Bioinforma. 2012, 10, 94-106. [CrossRef] [PubMed]

67. Zhang, W.-J.; Pedersen, C.; Kwaaitaal, M.; Gregersen, P.L.; Mørch, S.M.; Hanisch, S.; Kristensen, A.; Fuglsang, A.T.; Collinge, D.B.; Thordal-Christensen, H. Interaction of barley powdery mildew effector candidate CSEP0055 with the defence protein PR17c. Mol. Plant Pathol. 2012, 13, 1110-1119. [CrossRef]

68. Mészáros, K.; Nagy, E.; Bányai, J.; Kunos, V.; Cséplő, M.; Decsi, É.K.; Hoffmann, S.; Hoffmann, B. Investigation of drought tolerance of barley genotypes in a sand pipe system and under field conditions. In Proceedings of the 26th Hungarian Plant Breeding Science Workshop; Bóna, L., Karsai, I., Matuz, J., Pauk, J., Polgár, Z., Veisz, O., Eds.; Journal of Plant Research (Iranian Journal of Biology): Szeged, Hungary, 2020.

69. Xing, L.; Di, Z.; Yang, W.; Liu, J.; Li, M.; Wang, X.; Cui, C.; Wang, X.; Wang, X.; Zhang, R.; et al. Overexpression of ERF1-V from Haynaldia villosa can enhance the resistance of wheat to powdery mildew and increase the tolerance to salt and drought stresses. Front. Plant Sci. 2017, 8, 1948. [CrossRef] [PubMed] 